\title{
Wpływ temperatury na skuteczność działania cieczy przemywającej stosowanej w zabiegu cementowania otworu wiertniczego
}

\author{
Influence of temperature on the effectiveness of preflush fluid used in the cementing \\ of the borehole
}

\author{
Miłosz Kędzierski, Marcin Rzepka, Marcin Kremieniewski \\ Instytut Nafty i Gazu - Państwowy Instytut Badawczy
}

\begin{abstract}
STRESZCZENIE: W artykule przestawiono wyniki badania wpływu temperatury na skuteczność działania cieczy przemywającej. W wyniku przeprowadzonych badań uzyskano istotne informacje o oddziaływaniu cieczy wiertniczych na rdzeń skalny w warunkach podwyższonej temperatury. Badania zostały przeprowadzone dla dwóch wydatków tłoczenia cieczy przemywającej: 10,0 i 11,2 1/min przy czasie kontaktu cieczy ze skałą wynoszącym 4 i 6 minut. W celu realizacji badań przeprowadzono modyfikację symulatora przepływu cieczy wiertniczych dodając do niego płaszcz grzewczy umożliwiający podgrzanie cieczy wiertniczych do danej temperatury. Badania wykonano dla różnych temperatur: $25^{\circ} \mathrm{C}, 40^{\circ} \mathrm{C}$ i $60^{\circ} \mathrm{C}$. Do przeprowadzenia badań laboratoryjnych zostały wykorzystane trzy rodzaje płuczek wiertniczych (beziłowa z blokatorami, polimerowo-chlorkowa, solno-barytowa) i zaczynów cementowych stosowanych w warunkach przemysłowych oraz ciecz przemywająca sporządzona w Instytucie Nafty i Gazu - Państwowym Instytucie Badawczym z nowego rodzaju środków. Stopień oczyszczenia przestrzeni pierścieniowej określono za pomocą przyczepności na kontakcie kamień cementowy-skała. Na podstawie uzyskanych wyników stwierdzono, iż wraz ze wzrostem temperatury płuczki wiertniczej maleje skuteczność wymywania osadu za pomocą cieczy przemywającej. Skuteczność usuwania osadu płuczkowego uzależniona jest również od wydatku tłoczenia cieczy przemywającej oraz od czasu kontaktu tej cieczy z oczyszczaną powierzchnią. W przypadku każdej z płuczek wiertniczych największą skuteczność działania cieczy przemywającej uzyskano dla wydatku tłoczenia 11,2 1/min przy czasie kontaktu wynoszącym 6 minut w temperaturze $25^{\circ} \mathrm{C}$. Najniższy stopnień wymywania osadów płuczkowych po dwudniowym sezonowaniu próbek uzyskano dla wydatku tłoczenia cieczy przemywającej wynoszącym 10,0 1/min i czasie kontaktu 4 minuty w temperaturze $60^{\circ} \mathrm{C}$. Uzyskane wyniki przyczepności dla temperatury $25^{\circ} \mathrm{C}$ zawierały się w przedziale $60-90 \%$ wartości bazowej. Wartości przyczepności dla temperatury $40^{\circ} \mathrm{C}$ mieściły się $\mathrm{w}$ zakresie $45-60 \%$ przyczepności bazowej, zaś dla temperatury $60^{\circ} \mathrm{C}$ uzyskane wyniki zawierały się w przedziale $35-45 \%$ przyczepności bazowej.
\end{abstract}

Słowa kluczowe: ciecz przemywająca, przemywka, oczyszczenie przestrzeni pierścieniowej, symulator przepływu cieczy wiertniczych, uszczelnienie otworu wiertniczego.

\begin{abstract}
The article presents the results of investigation into the impact of temperature on the effectiveness of preflush fluid. The research showed significant information about the influence of drilling fluids on the rock core in conditions of elevated temperature. The testing was performed for two preflush fluid pumping rate: 10.0 and 11.2 1/min at the fluid contact time of 4 and 6 minutes. In order to carry out the tests, a modification of the drilling fluids flow simulator was made by adding a heating mantle to it, allowing the heating of drilling fluids to a given temperature. The tests were carried out at various temperatures: $25^{\circ} \mathrm{C}, 40^{\circ} \mathrm{C}$ and $60^{\circ} \mathrm{C}$. For laboratory tests various types of drilling muds (non-bentonite drilling mud, potassium chloride-polymer drilling mud, NaCl-barite drilling mud) were used, and cement slurries used in industrial conditions, as well as preflush fluid prepared from a new type of the additives in Oil and Gas Institute - National Research Institute. The degree of cleaning of the annular space was determined by the adhesion on the contact between the cement stone and the rock. Based on the analysis of the obtained results, it was found that the effectiveness of the filter cake removal decreased with the increase of temperature. The effectiveness of the mud cake removal depends on the preflush fluid pumping rate and the contact time of this fluid with the surface being cleaned. For each of the drilling muds, the highest efficiency of the preflush fluid was obtained for a pumping rate of $11.2 \mathrm{l} / \mathrm{min}$ with a contact time of 6 minutes at $25^{\circ} \mathrm{C}$. The lowest degree of filter cake removal after two-day hydration of the samples was obtained for a preflush fluid pumping rate of $10.0 \mathrm{l} / \mathrm{min}$ with a contact time of 6 minutes at $60^{\circ} \mathrm{C}$. Obtained adhesion results for the temperature of $25^{\circ} \mathrm{C}$ were in the range of $60-90 \%$ of the base adhesion. The adhesion values for $40^{\circ} \mathrm{C}$ were in the range of $45-60 \%$ of the basic adhesion, while for the temperature of $60^{\circ} \mathrm{C}$, the obtained results were in the range of $35-45 \%$ of the basic adhesion.
\end{abstract}

Key words: preflush fluid, wash fluid, cleaning of the annular space, drilling fluids flow simulator, borehole sealing.

Autor do korespondencji: M. Kędzierski, e-mail: milosz.kedzierski@inig.pl

Artykuł nadesłano do Redakcji 21.12.2018 r. Zatwierdzono do druku 21.03.2019 r. 


\section{Wprowadzenie}

Zabieg cementowania w otworach wiertniczych ma dwa główne cele: ograniczanie migracji płynów (np. wód słodkich, solanek, gazu ziemnego, ropy naftowej) między strefami w formacjach skalnych oraz uzyskanie trwałego połączenia kamienia cementowego w przestrzeni pierścieniowej pomiędzy ścianą otworu wiertniczego a kolumną rur okładzinowych (Nelson et al. 1990; Uliasz i in. 2015; Kremieniewski 2011, 2016). Cementowanie rozpoczyna się od przepłukania otworu wiertniczego płuczką wiertniczą o obniżonych parametrach reologicznych (Sauer, 1987; Smith, 1987). Po zapuszczeniu rur okładzinowych i obróbce płuczki wiertnicznej, do otworu wtłacza się sekwencje cieczy przemywających (rys. 1), które służą do oczyszczenia otworu i oddzieleniu płuczki od zaczynu cementowego (Kędzierski et al., 2018). Ciecze przemywające stosowane są głownie do oczyszczenia przestrzeni pierścieniowej i pozarurowej otworu wiertniczego przed zabiegiem cementowania. Ciecze buforowe mają natomiast za zadanie oddzielić poszczególne ciecze wiertnicze (płuczkę wiertniczą i zaczyn cementowy) oraz wypośrodkować parametry reologiczne poszczególnych cieczy w celu zapewnienia wymaganych charakterów przepływów hydraulicznych (Haut et al., 1979; Crook et al., 1987). Ciecze przemywające najczęściej zawierają w swoim składzie środki powierzchniowo czynne, dzięki czemu możliwe jest mocniejsze wypłukanie osadu płuczkowego, a tym samym wzrasta przyczepność oraz stopień związania zaczynu cementowego z rurami okładzinowymi i formacją skalną (Kremieniewski et al., 2018). Z kolei ciecze buforowe zawierają środki zwiększające lepkość i wytrzymałość strukturalną oraz dodatki obciążające w celu utrzymania wymaganego ciśnienia hydrostatycznego i nadania dodatkowej funkcji mechanicznego oczyszczania przestrzeni pierścieniowej przez obecności drobnych frakcji. Wybór rodzaju i składu cieczy przemywającej i buforowej uzależniony jest od wielu czynników, tj. warunków geologiczno-złożowych, rodzaju i właściwości płuczki wiertniczej, zaczynu cementowego oraz przyjętej technologii cementowania (Brice et al., 1964; Clark et al., 1973; Braghini et al., 2010).

Dokładne wyparcie płuczki wiertniczej za pomocą cieczy przemywających i zaczynu cementowego jest kluczowym czynnikiem decydującym o uzyskaniu odpowiedniej szczelności na kontakcie: formacja skalna-płaszcz cementowy-rura okładzinowa oraz wyeliminowaniu możliwości powstania niepożądanego zjawiska migracji gazu w kontakcie płaszcza cementowego $\mathrm{z}$ formacją skalną i powierzchnią rury okładzinowej (rys. 2). Poprawne oczyszczenie i uszczelnienie przestrzeni pierścieniowej przyczynia się do wieloletniej eksploatacji odwiertu, minimalizując niekorzystne działanie środowiska naturalnego na kolumnę rur okładzinowych (Kremieniewski, 2018).

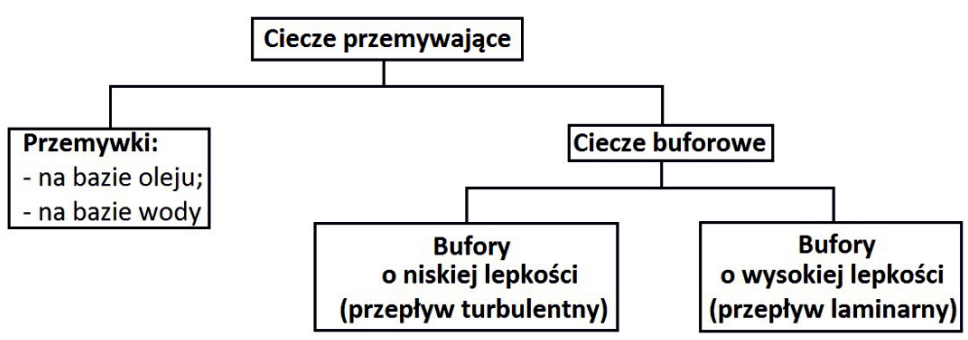

Rys. 1. Klasyfikacja cieczy przemywających (Lavrov et al., 2016)

Fig. 1. Classification of preflushes

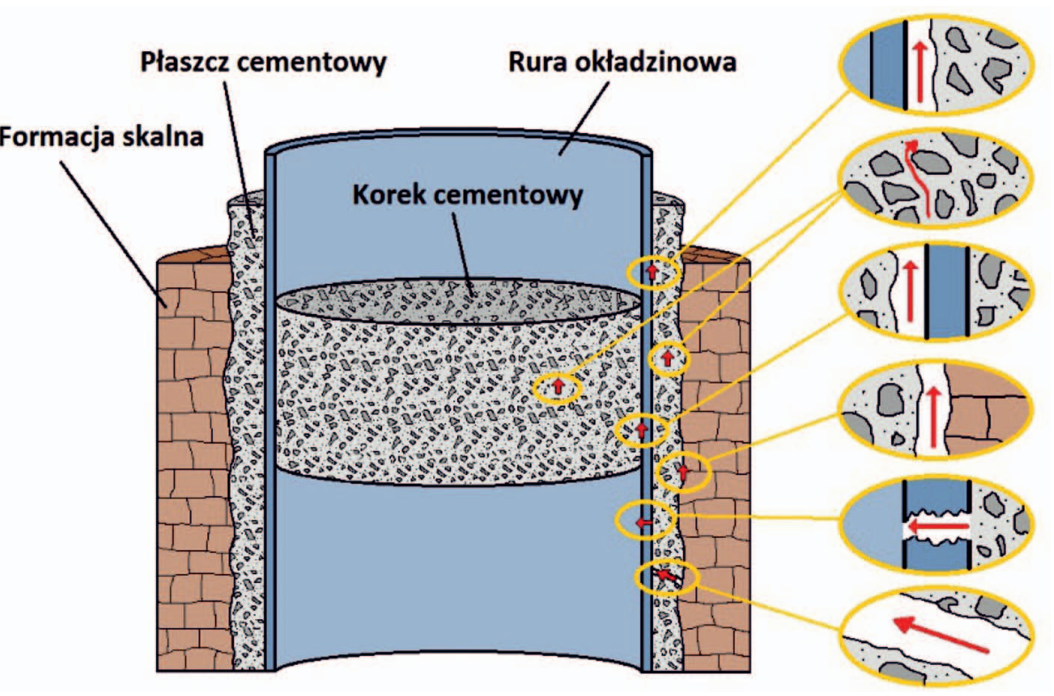

Rys. 2. Drogi migracji w zacementowanym otworze wiertniczym (Jasiński, 2016) Fig. 2. Migration paths in cemented borehole

\section{Część doświadczalna}

Podczas badań laboratoryjnych, których celem było określenie wpływu temperatury na skuteczność działania cieczy przemywającej stosowano próbki piaskowca pobranego z głębokości 300-400 m. Użyte w trakcie badań laboratoryjnych próbki piaskowca zostały wycięte w kształcie walca o średnicy zewnętrznej $25 \mathrm{~mm}$ i długości $60 \mathrm{~mm}$ (fot. 1).

Rdzenie piaskowca umieszczono w specjalnie skonstruowanym statywie (fot. 2, rys. 3) znajdującym się wewnątrz rury w stymulatorze przepływu cieczy wiertniczych.

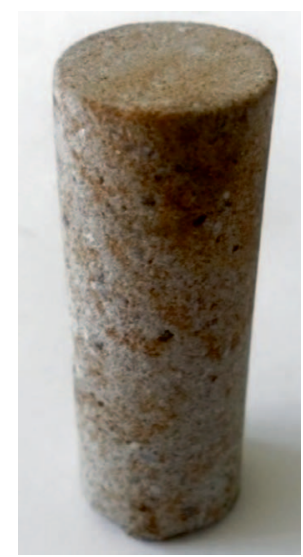

Fot. 1. Rdzeń wycięty z próbki piaskowca

Photo 1. Core cut out of a sandstone specimen 


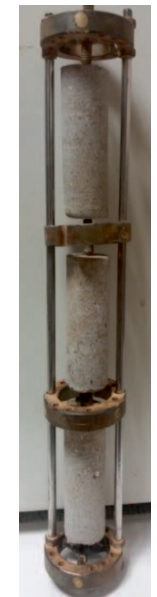

Fot. 2. Rdzenie piaskowca w statywie

Photo 2. Sandstone cores mounted on a tripod

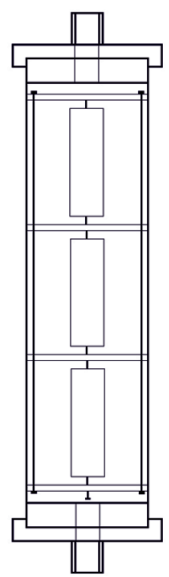

Rys. 3. Rura wraz ze statywem na rdzenie piaskowca

Fig. 3. Diagram of the sandstone cores placed on a tripod inside the plastic pipe
Pierwszym etapem przeprowadzonych badań laboratoryjnych było wytworzenie na rdzeniach piaskowca osadu z płuczki wiertniczej. Tworzenie osadu polegało na obmywaniu w czasie 1 godziny przepływającą płuczką trzech rdzeni umieszczonych w symulatorze przepływu cieczy wiertniczych. W celu utworzenia osadu na rdzeniach do badań laboratoryjnych zastosowano trzy płuczki wiertnicze stosowane w warunkach przemysłowych. Wydatek tłoczenia płuczki został określony na podstawie wcześniejszych badań laboratoryjnych.

W kolejnym etapie prowadzono przemywanie rdzeni cieczą przemywającą przez cztery i sześć minut dla dwóch wybranych wydatków tłoczenia: 10,2 oraz 11,2 1/min. Wydatki tłoczenia wyznaczono na podstawie obliczonej liczby Reynoldsa. Liczba Reynoldsa dla tych wydatków miała wartość zbliżoną do wartości krytycznej dla przepływu turbulentnego $(\operatorname{Re} \approx 3000)$. Oczyszczone $\mathrm{z}$ osadu rdzenie przygotowano do

Przedstawiony na rysunku 4 i fotografii 3 symulator do przepływu cieczy wiertniczych składa się z pompy z wirnikiem (1) zanurzanej w zbiorniku z cieczą wiertniczą (2) napędzanej silnikiem elektrycznym (3) poprzez pasek klinowy (4), rury wykonanej z PVC (5), wewnątrz której na specjalnym statywie (6) umieszcza się trzy rdzenie piaskowca oraz węża odprowadzającego płuczkę wiertniczą (wodę) (7) do zbiornika. Silnik, pompa oraz rura $\mathrm{z}$ PVC są przymocowane do dwóch statywów (8) zapewniających stabilność urządzenia. Przeprowadzono modyfikację urządzenia dodając do niego płaszcz grzewczy (9) umożliwiający podgrzanie cieczy wiertniczych do danej temperatury. Aby zapobiec utraty ciepła zastosowano izolację cieplną (10) wokół płaszcza grzewczego. Przepływ odbywał się w obiegu zamkniętym.

Badania wykonano dla różnych temperatur: $25^{\circ} \mathrm{C}, 40^{\circ} \mathrm{C}$ i $60^{\circ} \mathrm{C}$. Wydatek tłoczenia cieczy przemywającej oraz jej czas kontaktu z powierzchnią próbki zostały dobrane podczas badań wstępnych. Do badań przyjęto dwa wydatki tłoczenia wynoszące: $10,0 \mathrm{l} / \mathrm{min}$ i 11,2 1/min oraz dwa czasy kontaktu wynoszące 4 i 6 minut. Wytypowaną cieczą przemywającą był roztwór zawierający surfaktanty, tj. $0,2 \%$ środka niejonowego należącego do grupy etoksylowanych alkoholi tłuszczowych oraz $0,2 \%$ anionowego z grupy alkiloeterosiarczanów. Stopień oczyszczenia przestrzeni pierścieniowej określono za pomocą przyczepności na kontakcie kamień cementowy-skała. W badaniach wykorzystano trzy rodzaje płuczek otworowych (beziłową z blokatorami, polimerowo-chlorkową, solno-barytową) i trzy zaczyny cementowe zastosowane podczas realizacji otworów wiertniczych.

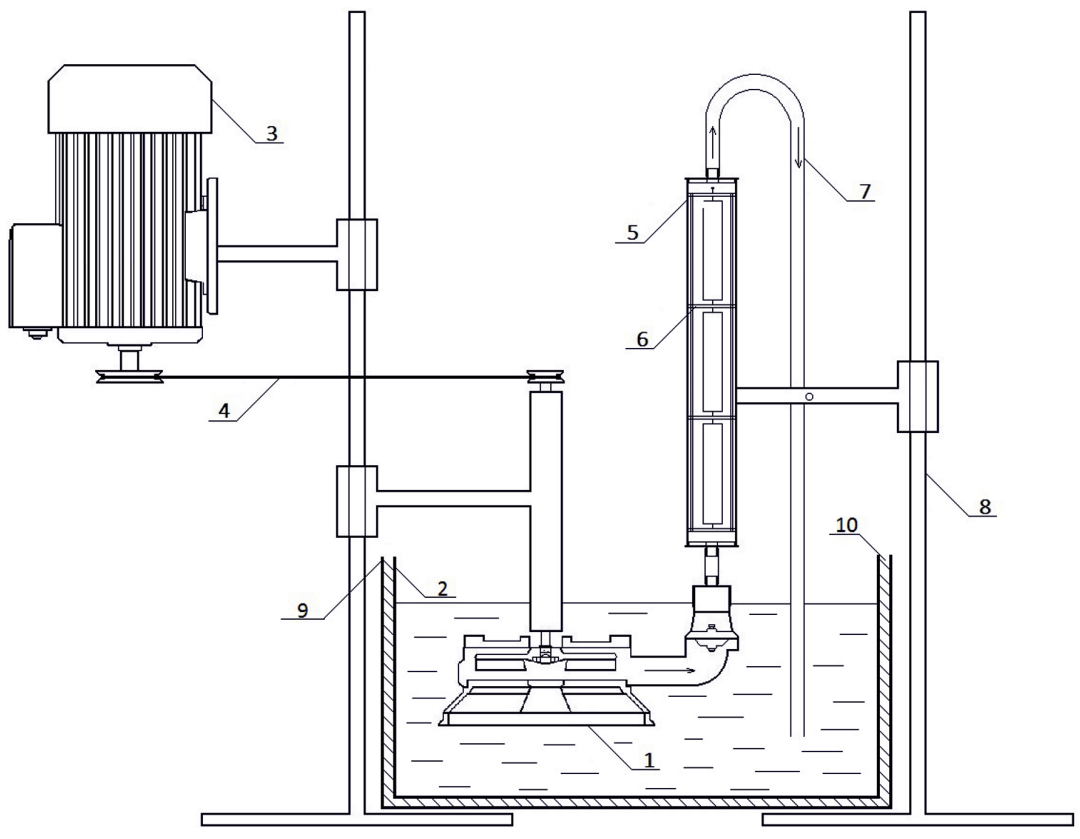

Rys. 4. Symulator przepływu cieczy wiertniczych

Fig. 4. Borehole drilling fluid flow simulator

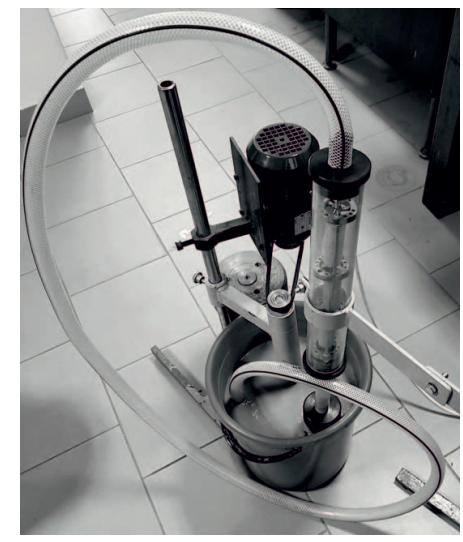

Fot. 3. Symulator przepływu cieczy wiertniczych (Kremieniewski et al., 2018)

Photo 3. Borehole drilling fluid flow simulator 
kolejnego etapu badań, których celem było określenie efektywności uszczelnienia przestrzeni pierścieniowej na kontakcie kamień cementowy-skała. Badania te przeprowadzono opierając się na pomiarze przyczepności kamienia cementowego do próbki skały. Rdzenie umieszczono centralnie wewnątrz pierścienia z tworzywa sztucznego, a następnie zalewano je przygotowanym zaczynem cementowym.

Następnie próbki sezonowano w temperaturze $25^{\circ} \mathrm{C}$ w środowisku wodnym przez okres dwóch dni. Po sezonowaniu umieszczano je między dwiema płytami maszyny wytrzymałościowej, gdzie mierzono siłę zerwania przyczepności

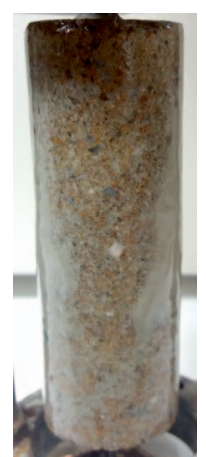

$25^{\circ} \mathrm{C}$

Czas kontaktu $4 \mathrm{~min}$

Wydatek tłoczenia 10,0 1/min

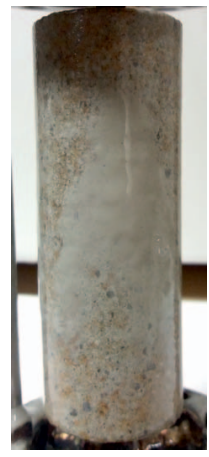

$40^{\circ} \mathrm{C}$

Czas kontaktu 4 min Wydatek tłoczenia 10,0 1/min

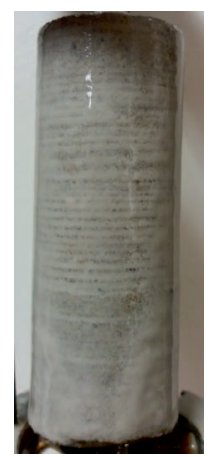

$60^{\circ} \mathrm{C}$

Czas kontaktu 4 min

Wydatek tłoczenia 10,0 1/min

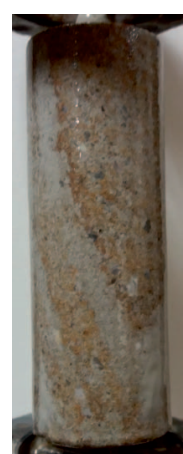

$25^{\circ} \mathrm{C}$

Czas kontaktu $4 \mathrm{~min}$

Wydatek tłoczenia 11,2 1/min

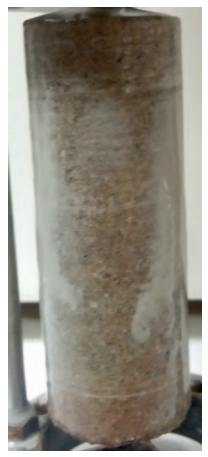

$40^{\circ} \mathrm{C}$

Czas kontaktu $4 \mathrm{~min}$ Wydatek tłoczenia 11,2 1/min

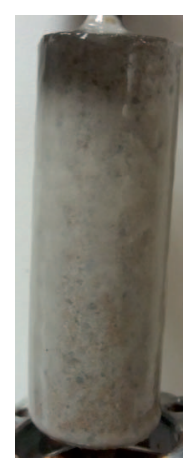

$60^{\circ} \mathrm{C}$

Czas kontaktu 4 min Wydatek tłoczenia 11,2 1/min

w kontakcie kamień cementowy-skała pod wpływem obciążenia przykładanego na próbkę.

Po każdym pomiarze siły potrzebnej do zerwania przyczepności pomiędzy kamieniem cementowym a skałą należało obliczyć przyczepność wyrażoną w MPa, według wzoru (1):

$$
\sigma_{p}=\frac{P}{S} \cdot 10^{-3}[\mathrm{MPa}]
$$

gdzie:

$P$ - to siła nacisku, powodująca zerwanie połączenia kamienia cementowego ze skałą $[\mathrm{kN}]$,

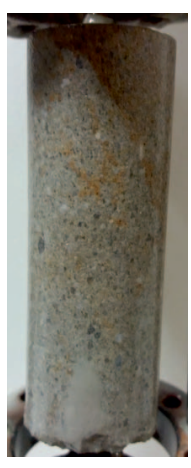

$25^{\circ} \mathrm{C}$

Czas kontaktu 6 min Wydatek tłoczenia 10,0 1/min

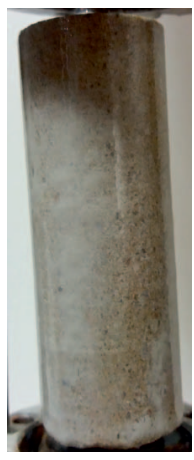

$40^{\circ} \mathrm{C}$

Czas kontaktu 6 min Wydatek tłoczenia 10,0 1/min

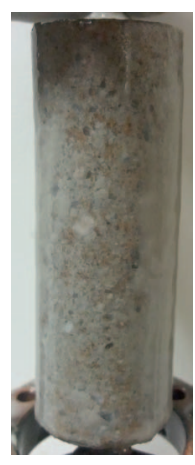

$60^{\circ} \mathrm{C}$

Czas kontaktu 6 min Wydatek tłoczenia 10,0 1/min

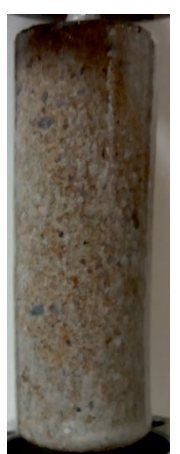

$25^{\circ} \mathrm{C}$

Czas kontaktu 6 min Wydatek tloczenia 11,2 1/min

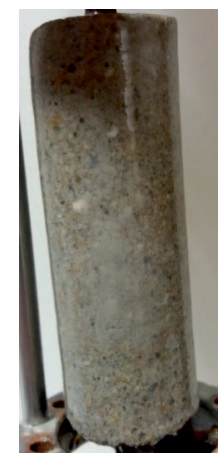

$40^{\circ} \mathrm{C}$

Czas kontaktu 6 min Wydatek tłoczenia 11,2 1/min

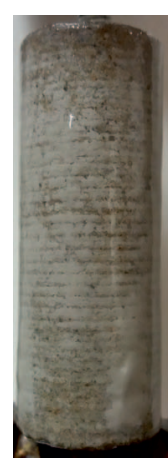

$60^{\circ} \mathrm{C}$

Czas kontaktu 6 min Wydatek tłoczenia 11,2 1/min

Fot. 4. Rdzenie piaskowca przemyte z osadu płuczkowego za pomocą cieczy przemywającej (płuczka beziłowa z blokatorami)

Photo 4. Sandstone cores washed from the mud cake using a preflush fluid (non-bentonite drilling mud) 
$s$ - to powierzchnia styku próbki skały z kamieniem cementowym $\left[\mathrm{m}^{2}\right]$.

Siłę nacisku $(P)$ odczytywano bezpośrednio ze wskaźnika maszyny wytrzymałościowej. Powierzchnia styku skały z kamieniem cementowym wynikała natomiast z geometrii form, w których rdzenie były zalewane zaczynem cementowym, stąd przyczepność na kontakcie kamień cementowy-skała $\sigma_{p}$ wyznaczono za pomocą wzoru (9):

$$
\sigma_{p}=\frac{P}{0,003456} \cdot 10^{-3}=\frac{P}{3,456}[\mathrm{MPa}]
$$

\section{Wyniki}

Najważniejszym badaniem, pozwalającym określić wpływ płuczek wiertniczych na jakość zacementowania, jest badanie przyczepności na kontakcie kamień cementowy-skała. Wyznaczono przyczepność bazową (tablice 1-3), do której porównywano wyniki kolejnych badań. W celu jej określenia rdzenie wycięte $z$ piaskowca zostały zalane zaczynem cementowym, z pominięciem etapu przemywania w cieczy przemywającej. Następnie wyznaczono przyczepność w kontakcie kamień cementowy-skała dla rdzeni przemytych cieczą przemywającą.

Po sezonowaniu próbek przez 2 dni w środowisku wodnym przeprowadzono badania przyczepności. Rezultaty zamieszczono w tablicach 4-6 oraz na rysunkach 5-7.

Dla płuczki beziłowej z blokatorami w temperaturze $25^{\circ} \mathrm{C}$ po dwudniowym sezonowaniu próbek najwyższą skuteczność
Tablica 1. Bazowa przyczepność w kontakcie kamień cementowy-skała (płuczka beziłowa z blokatorami)

Table 1. Base adhesion on the contact between the bound cement and the rock (non-bentonite drilling mud)

\begin{tabular}{|l|c|c|}
\cline { 2 - 3 } & $\begin{array}{c}\text { Sila zerwania } \\
\text { przyczepności } \\
{[\mathbf{k N}]}\end{array}$ & $\begin{array}{c}\text { Przyczepność na kontakcie } \\
\text { kamień cementowy-skala } \\
{[\mathbf{M P a}]}\end{array}$ \\
\hline \hline Próbka bazowa & 9,1 & 2,63 \\
\hline $\begin{array}{l}\text { Próbka z osadem } \\
\text { bez przemywania }\end{array}$ & 1,8 & 0,52 \\
\hline
\end{tabular}

Tablica 2. Bazowa przyczepność na kontakcie kamień cementowy-skała (płuczka solno-barytowa)

Table 2. Base adhesion on the contact between the bound cement and the rock ( $\mathrm{NaCl}$-barite drilling mud)

\begin{tabular}{|l|c|c|}
\cline { 2 - 3 } & $\begin{array}{c}\text { Sila zerwania } \\
\text { przyczepności } \\
{[\mathbf{k N}]}\end{array}$ & $\begin{array}{c}\text { Przyczepność na kontakcie } \\
\text { kamień cementowy-skala } \\
{[\mathrm{MPa}]}\end{array}$ \\
\hline \hline Próbka bazowa & 6,2 & 1,79 \\
\hline $\begin{array}{l}\text { Próbka z osadem } \\
\text { bez przemywania }\end{array}$ & 0,8 & 0,23 \\
\hline
\end{tabular}

Tablica 3. Bazowa przyczepność na kontakcie kamień cementowy-skała (płuczka polimerowo-chlorkowa)

Table 3. Base adhesion on the contact between the bound cement and the rock (chloride-polymer drilling mud)

\begin{tabular}{|l|c|c|}
\cline { 2 - 3 } & $\begin{array}{c}\text { Sila zerwania } \\
\text { przyczepności } \\
{[\mathbf{k N}]}\end{array}$ & $\begin{array}{c}\text { Przyczepność na kontakcie } \\
\text { kamień cementowy-skala } \\
{[\mathbf{M P a}]}\end{array}$ \\
\hline \hline Próbka bazowa & 8,2 & 2,37 \\
\hline $\begin{array}{l}\text { Próbka z osadem } \\
\text { bez przemywania }\end{array}$ & 1,5 & 0,43 \\
\hline
\end{tabular}

Tablica 4. Wartość przyczepności w kontakcie kamień cementowy-skała dla różnych temperatur $\left(25^{\circ} \mathrm{C}, 40^{\circ} \mathrm{C}\right.$ i $\left.60^{\circ} \mathrm{C}\right)$, wydatku tłoczenia 11,2 1/min i 10,0 1/min oraz czasów kontaktu 4 i 6 minut (płuczka beziłowa z blokatorami)

Table 4. Adhesion between the bound cement and the rock for different temperatures $\left(25^{\circ} \mathrm{C}, 40^{\circ} \mathrm{C}\right.$ and $\left.60^{\circ} \mathrm{C}\right)$, pumping rate of $11.21 / \mathrm{min}$ and $10.0 \mathrm{l} /$ and contact times of 4 and 6 minutes (non-bentonite drilling mud)

\begin{tabular}{|c|c|c|c|c|c|}
\hline Temperatura & $\begin{array}{c}\text { Wydatek toczenia } \\
\text { cieczy przemywającej }\end{array}$ & $\begin{array}{c}\text { Czas kontaktu } \\
\text { cieczy przemywającej } \\
\text { ze skałą } \\
\end{array}$ & $\begin{array}{l}\text { Sila rozerwania } \\
\text { przyczepności }\end{array}$ & $\begin{array}{c}\text { Przyczepność } \\
\text { w kontakcie kamień } \\
\text { cementowy-skała }\end{array}$ & \multirow[t]{2}{*}{$\begin{array}{l}\text { Procentowa zmiana } \\
\text { przyczepności w stosunku } \\
\text { do przyczepności bazowej }\end{array}$} \\
\hline$\left[{ }^{\circ} \mathbf{C}\right]$ & {$[1 / \mathrm{min}]$} & [min] & {$[\mathbf{k N}]$} & [MPa] & \\
\hline \multirow{4}{*}{25} & 10,0 & 4 & 5,6 & 1,62 & $\downarrow 38 \%$ \\
\hline & 11,2 & 4 & 6,1 & 1,76 & $\downarrow 33 \%$ \\
\hline & 10,0 & 6 & 6,6 & 1,91 & $\downarrow 27 \%$ \\
\hline & 11,2 & 6 & 7,1 & 2,05 & $\downarrow 22 \%$ \\
\hline \multirow{4}{*}{40} & 10,0 & 4 & 4,2 & 1,22 & $\downarrow 54 \%$ \\
\hline & 11,2 & 4 & 4,4 & 1,27 & $\downarrow 46 \%$ \\
\hline & 10,0 & 6 & 5,0 & 1,45 & $\downarrow 45 \%$ \\
\hline & 11,2 & 6 & 5,5 & 1,59 & $\downarrow 40 \%$ \\
\hline \multirow{4}{*}{60} & 10,0 & 4 & 3,1 & 0,90 & $\downarrow 66 \%$ \\
\hline & 11,2 & 4 & 3,3 & 0,95 & $\downarrow 64 \%$ \\
\hline & 10,0 & 6 & 3,5 & 1,01 & $\downarrow 62 \%$ \\
\hline & 11,2 & 6 & 4,0 & 1,16 & $\downarrow 56 \%$ \\
\hline
\end{tabular}


Tablica 5. Wartość przyczepność w kontakcie kamień cementowy-skała dla różnych temperatur $\left(25^{\circ} \mathrm{C}, 40^{\circ} \mathrm{C}\right.$ i $\left.60^{\circ} \mathrm{C}\right)$, wydatku tłoczenia 11,2 1/min i 10,0 1/min oraz czasów kontaktu 4 i 6 minut (płuczka solno-barytowa)

Table 5. Adhesion between the bound cement and the rock for different temperatures $\left(25^{\circ} \mathrm{C}, 40^{\circ} \mathrm{C}\right.$ and $\left.60^{\circ} \mathrm{C}\right)$, pumping rate of $11.21 / \mathrm{min}$ and $10.0 \mathrm{l} /$ and contact times of 4 and 6 minutes (NaCl-barite drilling mud)

\begin{tabular}{|c|c|c|c|c|c|}
\hline Temperatura & $\begin{array}{l}\text { Wydatek toczenia } \\
\text { cieczy przemywającej }\end{array}$ & $\begin{array}{c}\text { Czas kontaktu } \\
\text { cieczy przemywającej } \\
\text { ze skałą }\end{array}$ & $\begin{array}{l}\text { Sila rozerwania } \\
\text { przyczepności }\end{array}$ & $\begin{array}{c}\text { Przyczepność } \\
\text { w kontakcie kamień } \\
\text { cementowy-skala }\end{array}$ & \multirow[t]{2}{*}{$\begin{array}{l}\text { Procentowa zmiana } \\
\text { przyczepności w stosunku } \\
\text { do przyczepności bazowej }\end{array}$} \\
\hline$\left[{ }^{\circ} \mathbf{C}\right]$ & {$[1 / \mathrm{min}]$} & {$[\mathrm{min}]$} & {$[\mathrm{kN}]$} & [MPa] & \\
\hline \multirow{4}{*}{25} & 10,0 & 4 & 4,0 & 1,16 & $\downarrow 35 \%$ \\
\hline & 11,2 & 4 & 4,4 & 1,27 & $\downarrow 29 \%$ \\
\hline & 10,0 & 6 & 5,2 & 1,5 & $\downarrow 16 \%$ \\
\hline & 11,2 & 6 & 5,7 & 1,65 & $\downarrow 8 \%$ \\
\hline \multirow{4}{*}{40} & 10,0 & 4 & 3,0 & 0,87 & $\downarrow 52 \%$ \\
\hline & 11,2 & 4 & 3,1 & 0,9 & $\downarrow 50 \%$ \\
\hline & 10,0 & 6 & 3,5 & 1,01 & $\downarrow 44 \%$ \\
\hline & 11,2 & 6 & 3,8 & 1,1 & $\downarrow \mathbf{3 9 \%}$ \\
\hline \multirow{4}{*}{60} & 10,0 & 4 & 2,3 & 0,67 & $\downarrow 63 \%$ \\
\hline & 11,2 & 4 & 2,5 & 0,72 & $\downarrow 60 \%$ \\
\hline & 10,0 & 6 & 2,6 & 0,75 & $\downarrow \mathbf{5 8 \%}$ \\
\hline & 11,2 & 6 & 2,8 & 0,81 & $\downarrow 55 \%$ \\
\hline
\end{tabular}

Tablica 6. Wartość przyczepność w kontakcie kamień cementowy-skała dla różnych temperatur $\left(25 \mathrm{C}, 40^{\circ} \mathrm{C}\right.$ i $\left.60^{\circ} \mathrm{C}\right)$, wydatku tłoczenia 11,2 1/min i 10,0 1/min oraz czasów kontaktu 4 i 6 minut (płuczka polimerowo-chlorkowa)

Table 6. Adhesion between the bound cement and the rock for different temperatures $\left(25^{\circ} \mathrm{C}, 40^{\circ} \mathrm{C}\right.$ and $\left.60^{\circ} \mathrm{C}\right)$, pumping rate of $11.21 / \mathrm{min}$ and $10.0 \mathrm{l} /$ and contact times of 4 and 6 minutes (chloride-polymer drilling mud)

\begin{tabular}{|c|c|c|c|c|c|}
\hline Temperatura & $\begin{array}{l}\text { Wydatek toczenia } \\
\text { cieczy przemywającej }\end{array}$ & $\begin{array}{c}\text { Czas kontaktu } \\
\text { cieczy przemywającej } \\
\text { ze skałą }\end{array}$ & $\begin{array}{l}\text { Sila rozerwania } \\
\text { przyczepności }\end{array}$ & $\begin{array}{l}\text { Przyczepność na } \\
\text { kontakcie kamień } \\
\text { cementowy-skala }\end{array}$ & $\begin{array}{c}\text { Procentowa zmiana } \\
\text { przyczepności w stosunku }\end{array}$ \\
\hline$\left[{ }^{\circ} \mathbf{C}\right]$ & {$[1 / \mathrm{min}]$} & {$[\min ]$} & {$[\mathrm{kN}]$} & [MPa] & \\
\hline \multirow{4}{*}{25} & 10,0 & 4 & 5,2 & 1,5 & $\downarrow 37 \%$ \\
\hline & 11,2 & 4 & 5,9 & 1,71 & $\downarrow 28 \%$ \\
\hline & 10,0 & 6 & 6,2 & 1,79 & $\downarrow 24 \%$ \\
\hline & 11,2 & 6 & 6,8 & 1,97 & $\downarrow 17 \%$ \\
\hline \multirow{4}{*}{40} & 10,0 & 4 & 3,9 & 1,13 & $\downarrow 52 \%$ \\
\hline & 11,2 & 4 & 4,1 & 1,19 & $\downarrow \mathbf{5 0 \%}$ \\
\hline & 10,0 & 6 & 4,8 & 1,39 & $\downarrow 41 \%$ \\
\hline & 11,2 & 6 & 5,0 & 1,45 & $\downarrow 39 \%$ \\
\hline \multirow{4}{*}{60} & 10,0 & 4 & 2,9 & 0,84 & $\downarrow 65 \%$ \\
\hline & 11,2 & 4 & 3,1 & 0,9 & $\downarrow 62 \%$ \\
\hline & 10,0 & 6 & 3,3 & 0,95 & $\downarrow 60 \%$ \\
\hline & 11,2 & 6 & 3,7 & 1,07 & $\downarrow \mathbf{5 5 \%}$ \\
\hline
\end{tabular}

wymywania osadu płuczkowego za pomocą cieczy przemywającej uzyskano dla wydatku tłoczenia 11,2 1/min przy czasie kontaktu wynoszącym 6 minut. Wartość przyczepności uzyskanej w tym przypadku wynosiła 2,05 $\mathrm{MPa}$, co stanowiło około $80 \%$ wartości bazowej. Uzyskane wyniki przyczepności dla temperatury $25^{\circ} \mathrm{C}$ zawierały się w przedziale 1,62-2,05 MPa, co stanowiło około 60-80\% wartości bazowej. Wartości przyczepności dla temperatury $40^{\circ} \mathrm{C}$ mieściły się w zakresie 1,22-1,59 MPa, co stanowiło 45-60\% przyczepności bazowej. Najmniejszą skuteczność w usuwaniu osadów uzyskano w temperaturze $60^{\circ} \mathrm{C}$. Uzyskane wyniki zawierały się w przedziale 0,9-1,16 MPa. Analizując otrzymane wyniki przyczepności w kontakcie kamień cementowy-skała, można wysnuć wniosek, iż wraz ze wzrostem 


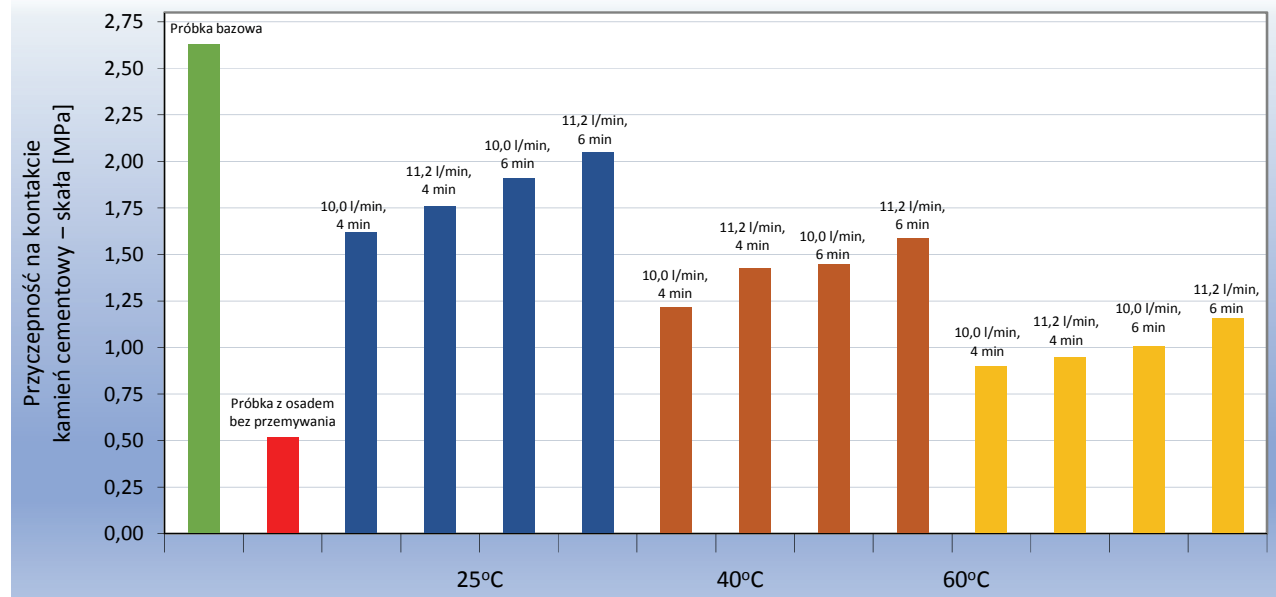

Rys. 5. Wartość przyczepność w kontakcie kamień cementowy-skała dla różnych temperatur $\left(25^{\circ} \mathrm{C}, 40^{\circ} \mathrm{C}\right.$ i $\left.60^{\circ} \mathrm{C}\right)$, wydatku tłoczenia 11,2 1/min i 10,0 1/min oraz czasów kontaktu 4 i 6 minut (płuczka beziłowa z blokatorami)

Fig. 5. Adhesion between the bound cement and the rock for different temperatures $\left(25^{\circ} \mathrm{C}, 40^{\circ} \mathrm{C}\right.$ and $\left.60^{\circ} \mathrm{C}\right)$, pumping rate of $11.21 / \mathrm{min}$ and $10.0 \mathrm{l} /$ and contact times of 4 and 6 minutes (non-bentonite drilling mud)

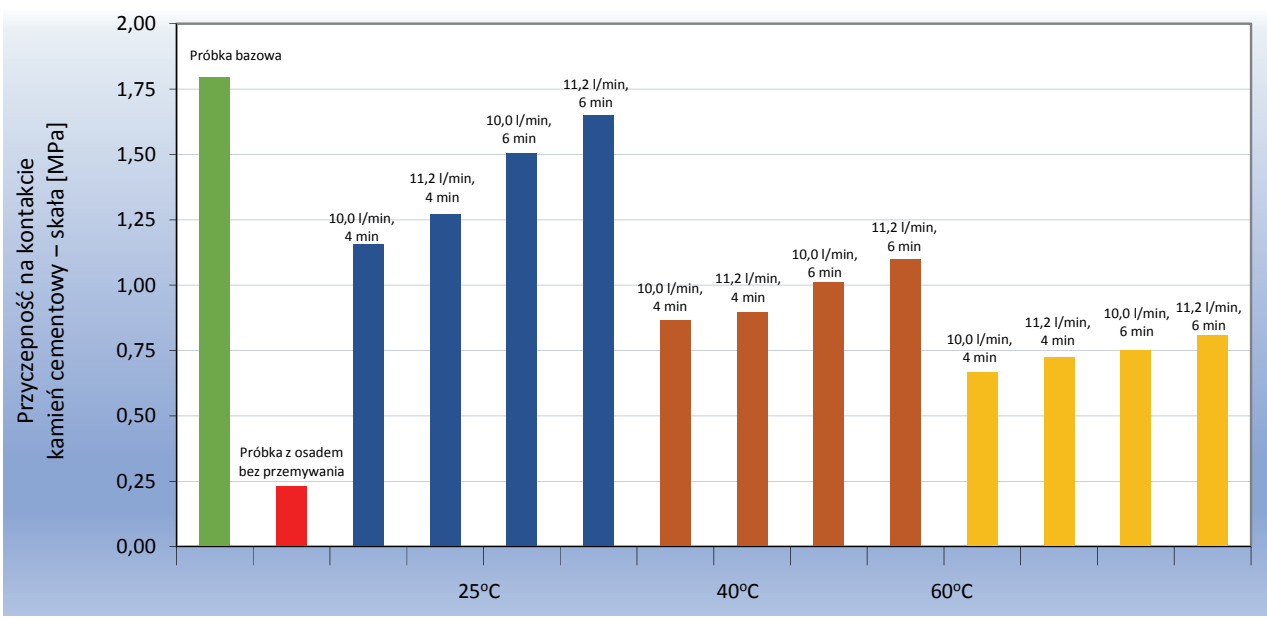

Rys. 6. Wartość przyczepność w kontakcie kamień cementowy-skała dla różnych temperatur $\left(25^{\circ} \mathrm{C}, 40^{\circ} \mathrm{C}\right.$ i $\left.60^{\circ} \mathrm{C}\right)$, wydatku tłoczenia 11,2 1/min i 10,0 1/min oraz czasów kontaktu 4 i 6 minut (płuczka solno-barytowa)

Fig. 6. Adhesion between the bound cement and the rock for different temperatures $\left(25^{\circ} \mathrm{C}, 40^{\circ} \mathrm{C}\right.$ and $\left.60^{\circ} \mathrm{C}\right)$, pumping rate of $11.21 / \mathrm{min}$ and $10.0 \mathrm{l} /$ and contact times of 4 and 6 minutes (NaCl-barite drilling mud)

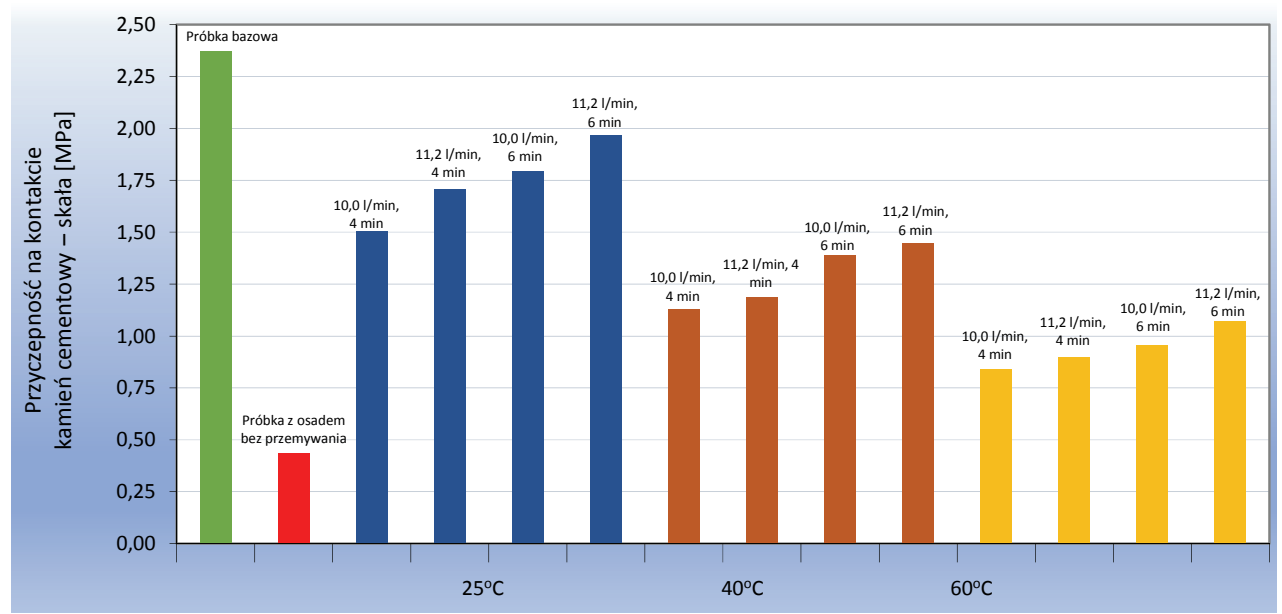

Rys. 7. Wartość przyczepność w kontakcie kamień cementowy-skała dla różnych temperatur $\left(25^{\circ} \mathrm{C}, 40^{\circ} \mathrm{C}\right.$ i $\left.60^{\circ} \mathrm{C}\right)$, wydatku tłoczenia 11,2 1/min i 10,0 1/min oraz czasów kontaktu 4 i 6 minut (płuczka polimerowo-chlorkowa)

Fig. 7. Adhesion between the bound cement and the rock for different temperatures $\left(25^{\circ} \mathrm{C}, 40^{\circ} \mathrm{C}\right.$ and $\left.60^{\circ} \mathrm{C}\right)$, pumping rate of $11.21 / \mathrm{min}$ and $10.0 \mathrm{l} /$ and contact times of 4 and 6 minutes (chloride-polymer drilling mud) 
temperatury płuczki wiertniczej maleje skuteczność usuwania osadu płuczkowego.

Dla płuczki solno-barytowej w temperaturze $25^{\circ} \mathrm{C}$ po dwudniowym sezonowaniu próbek najwyższą skuteczność działania cieczy przemywającej uzyskano dla wydatku tłoczenia 11,2 1/min przy czasie kontaktu wynoszącym 6 minut. Wartość przyczepności uzyskanej dla tych parametrów przemywania wynosiła 1,65 MPa, co stanowiło $90 \%$ wartości bazowej. Uzyskane wyniki przyczepności dla temperatury $25^{\circ} \mathrm{C}$ zawierały się w przedziale 1,16-1,65 MPa, co stanowiło około 65-90\% wartości bazowej. Wyniki pomiaru przyczepności w temperaturze $40^{\circ} \mathrm{C}$ były niższe niż uzyskiwane w temperaturze $25^{\circ} \mathrm{C}$. Najniższy stopnień wymywania osadów płuczkowych w temperaturze $40^{\circ} \mathrm{C}$ po dwudniowym sezonowaniu próbek uzyskano dla wydatku tłoczenia cieczy przemywającej wynoszącym 10,0 1/min i czasie kontaktu 4 minuty. Wartości przyczepności dla temperatury $40^{\circ} \mathrm{C}$ mieściły się w zakresie 0,87-1,1 MPa, co stanowiło 50-60\% przyczepności bazowej. Najmniejszą skuteczność w usuwaniu osadów uzyskano w temperaturze $60^{\circ} \mathrm{C}$. Uzyskane wyniki zawierały się w przedziale 0,67-0,81 MPa. Podobnie, jak w temperaturach $25^{\circ} \mathrm{C}$ i $40^{\circ} \mathrm{C}$ największą przyczepność uzyskano dla wydatku tłoczenia 11,2 1/min i czasie kontaktu 6 minut.

W przypadku płuczki polimerowo-chlorkowej uzyskane wyniki przyczepności dla temperatury $25^{\circ} \mathrm{C}$ zawierały się w przedziale 1,5-1,97 MPa, co stanowiło około 60-80\% wartości bazowej. Wartości przyczepności dla temperatury $40^{\circ} \mathrm{C}$ mieściły się w zakresie 1,13-1,45 MPa, co stanowiło 50-60\% przyczepności bazowej. Najmniejszą skuteczność w usuwaniu osadów uzyskano w temperaturze $60^{\circ} \mathrm{C}$. Uzyskane wyniki zawierały się w przedziale 0,87-1,07 MPa. Dla każdej temperatury największe wartości przyczepności uzyskano dla wydatku tłoczenia 11,2 1/min przy czasie kontaktu 6 minut. Na podstawie uzyskanych wyników można zaobserwować, iż skuteczność wymywania osadu płuczkowego maleje wraz ze wzrostem temperatury płuczki wiertniczej.

\section{Wnioski}

Na podstawie przeprowadzonych badań można wyciągnąć następujące wnioski:

1. Skuteczność usuwania osadu płuczkowego uzależniona jest od wydatku tłoczenia cieczy przemywającej oraz od czasu kontaktu tej cieczy z oczyszczaną powierzchnią.

2. Wytworzony na powierzchni próbki materiału skalnego osad z płuczki solno-barytowej był najbardziej trwały i trudniejszy w usunięciu przez ciecz przemywającą w porównaniu z osadami wytworzonymi przez płuczką beziłową z blokatorami i polimerowo-chlorkową.
3. W przypadku zastosowania płuczki beziłowej z blokatorami uzyskane wyniki przyczepności kamienia cementowego do rdzenia piaskowca dla temperatury $25^{\circ} \mathrm{C}$ zawierały się w przedziale 1,62-2,05 $\mathrm{MPa}$, co stanowiło około 60-80\% wartości przyczepności bazowej. Wartości przyczepności dla temperatury $40^{\circ} \mathrm{C}$ mieściły się w zakresie 1,22-1,59 MPa, co stanowiło 45-60\% przyczepności bazowej. Najmniejszą skuteczność w usuwaniu osadów uzyskano w temperaturze $60^{\circ} \mathrm{C}$. Uzyskane wyniki przyczepności próbek skalnych zawierały się w przedziale 0,9-1,16 $\mathrm{MPa}$, co stanowiło 35-45\% przyczepności bazowej.

4. Dla płuczki solno-barytowej w temperaturze $25^{\circ} \mathrm{C}$ po dwudniowym sezonowaniu próbek uzyskane wyniki przyczepności kamienia cementowego do rdzenia piaskowca dla temperatury $25^{\circ} \mathrm{C}$ zawierały się w przedziale 1,16-1,65 MPa, co stanowiło około 65-90\% wartości bazowej. Wartości przyczepności dla temperatury $40^{\circ} \mathrm{C}$ mieściły się w zakresie 0,87-1,1 MPa, co stanowiło 50-60\% przyczepności bazowej. Najmniejszą skuteczność w usuwaniu osadów uzyskano w temperaturze $60^{\circ} \mathrm{C}$. Wartości przyczepności w kontakcie kamień cementowy-skała zawierały się w przedziale $0,67-0,81 \mathrm{MPa}$, co stanowiło $37-45 \%$ przyczepności bazowej.

5. W przypadku płuczki polimerowo-chlorkowej uzyskane wyniki przyczepności kamienia cementowego do rdzenia piaskowca dla temperatury $25^{\circ} \mathrm{C}$ zawierały się w przedziale 1,5-1,97 MPa, co stanowiło około 60-80\% wartości bazowej. Wartości przyczepności dla temperatury $40^{\circ} \mathrm{C}$ mieściły się w zakresie 1,13-1,45 MPa, co stanowiło 50-60\% przyczepności bazowej. Najmniejszą skuteczność w usuwaniu osadów uzyskano w temperaturze $60^{\circ} \mathrm{C}$. Uzyskane wyniki zawierały się w przedziale $0,87-1,07 \mathrm{MPa}$, co stanowiło 35-45\% przyczepności bazowej.

6. W przypadku każdej z płuczek wiertniczych największą skuteczność działania cieczy przemywającej uzyskano dla wydatku tłoczenia 11,2 1/min przy czasie kontaktu wynoszącym 6 minut w temperaturze $25^{\circ} \mathrm{C}$.

7. Najniższy stopnień wymywania osadów płuczkowych po dwudniowym sezonowaniu próbek uzyskano dla wydatku tłoczenia cieczy przemywającej wynoszącym 10,0 1/min i czasie kontaktu 4 minuty.

8. Na podstawie uzyskanych wyników można zaobserwować, iż wraz ze wzrostem temperatury płuczki wiertniczej maleje skuteczność wymywania osadu za pomocą cieczy przemywającej. W związku z czym należałoby podjąć próby zastosowania w składzie cieczy przemywającej środków dyspergujących, które spowodowałyby rozrzedzenie płuczki pozostającej na ścianie otworu wiertniczego, co wpłynęłoby na wzrost przyczepności kamienia cementowego do skały w wyższej temperaturze. 
Artykuł powstał na podstawie pracy badawczej pt.: Określenie wpływu temperatury na skuteczność działania cieczy przemywajacych - praca INiG - PIB na zlecenie MNiSW; nr zlecenia: 19/KW/18, nr archiwalny DK-4100/19/18.

\section{Literatura}

Braghini A. et al., 2010. Effect of Rheology on Flow Displacement during Cementing Process in Oil Wells. Uberlanda, MG, Brazylia: $13^{\text {th }}$ Brazilian Congress of Thermal Sciences and Engineering. Conference materials.

Brice Jr. J.W., Holmes B.C., 1964. Engineered Casing Cementing Programs Using Turbulent Flow Techniques. Society of Petroleum Engineers. DOI: 10.2118/742-PA.

Clark C.R., Carter L.G., 1973. Mud Displacement with Cement Slurries. J. Pet. Tech., 3-19.

Crook R.J., Keller S.R., Wilson M.A., 1987. Deviated Wellbore Cementing: Part 2 - Solutions. JPT, 961-966.

Haut R.C., Crook R.J., 1979. Primary Cementing: The Mud Displacement Process. Society of Petroleum Engineers. DOI: 10.2118/8253-MS.

Jasiński B., 2016. Ocena wpływu cieczy przemywającej na jakość zacementowania rur w otworze wiertniczym po użyciu płuczki glikolowo-potasowej. Nafta-Gaz, 6: 413-421. DOI: 10.18668/ NG.2016.06.04.

Kędzierski M., Kremieniewski M., Rzepka M., 2018. Wpływ wydatku tłoczenia cieczy przemywającej na stopień oczyszczenia przestrzeni pierścieniowej. Nafta-Gaz, 5: 365-371. DOI: 10.18668/ NG.2018.05.03.

Kremieniewski M., 2011. Proces migracji gazu w trakcie wiązania zaczynu cementowego. Nafta-Gaz, 3: 175-181.

Kremieniewski M., Kędzierski M., Rzepka M., 2018. Poprawa oczyszczania przestrzeni pierścieniowej otworu wiertniczego

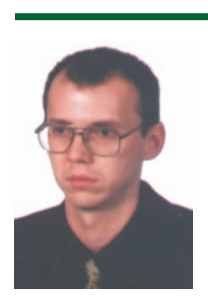

Dr inż. Marcin RZEPKA

Kierownik Laboratorium Zaczynów Uszczelniających w Zakładzie Technologii Wiercenia

Instytut Nafty i Gazu - Państwowy Instytut Badawczy ul. Lubicz $25 \mathrm{~A}$

31-503 Kraków

E-mail: marcin.rzepka@inig.pl przed zabiegiem cementowania. Prace Naukowe Instytutu Nafty i Gazu - Państwowego Instytutu Badawczego, 220: 1-172. DOI: 10.18668/PN2018.220.

Kremieniewski M., Kędzierski M., Rzepka M., 2018. Symulator przepływu cieczy wiertniczych - zasada pomiaru i możliwości badawcze. Nafta-Gaz, 7: 518-525. DOI: 10.18668/NG.2018.07.05.

Kremieniewski M., Rzepka M. 2016. Przyczyny i skutki przepływu gazu w zacementowanej przestrzeni pierścieniowej otworu wiertniczego oraz metody zapobiegania temu zjawisku. Nafta-Gaz, 9: 722-728. DOI: 10.18668/NG.2016.09.06.

Lavrov A., Torsaeter M. 2016. Physics and Mechanics of Primary Well Cementing. Springer: 25-61.

Nelson E.B., 1990. Well Cementing. Houston, Teksas, USA: Schlumberger Educational Service.

Sauer C.W., 1987. Mud Displacement During Cementing: A State of the Art. JPT, 1091-1101.

Smith D.K., 1986. Cementing. Society of Petroleum Engineers. Monograph Series.

Uliasz M., Zima G., Błaż S., Jasiński B., 2015. Ocena właściwości cieczy wiertniczych w aspekcie zapobiegania migracji gazu w otworach na przedgórzu Karpat. Nafta-Gaz, 1: 11-17.

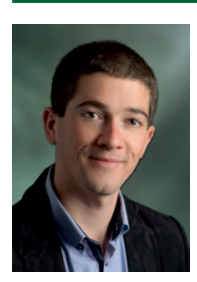

Mgr inż. Miłosz KĘDZIERSKI

Specjalista inżynieryjno-techniczny w Zakładzie Technologii Wiercenia

Instytut Nafty i Gazu - Państwowy Instytut Badawczy ul. Lubicz $25 \mathrm{~A}$

31-503 Kraków

E-mail: milosz.kedzierski@inig.pl

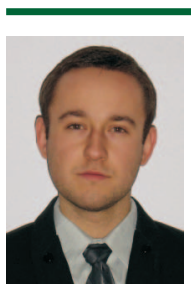

Dr inż. Marcin KREMIENIEWSKI

Adiunkt w Zakładzie Technologii Wiercenia Instytut Nafty i Gazu - Państwowy Instytut Badawczy ul. Lubicz 25 A

31-503 Kraków

E-mail:marcin.kremieniewski@inig.pl 